\title{
Morphometric Analysis of the Oil Palm Pollinating Weevil, Elaeidobius kamerunicus (Faust, 1878) (Coleoptera: Curculionidae) from Oil Palm Plantations in Malaysia
}

\author{
Dzulhelmi MUHAMMAD NASIR ${ }^{1}$ \\ Nabeel Ata ABDUL MUNEIM ${ }^{3}$ \\ Nurul-Fatihah ABD LATIP5 $\quad$ Suriyanti SU ${ }^{6} \quad$ Izfa Riza HAZMI ${ }^{7, *}$ \\ 1,3,4Malaysian Palm Oil Board, 6 Persiaran Institusi, \\ Bandar Baru Bangi, 43000 Kajang, Selangor, MALAYSIA \\ ${ }^{2}$ Institute of Tropical Aquaculture and Fisheries, Universiti Malaysia \\ Terengganu, 21030 Kuala Nerus, Terengganu, MALAYSIA \\ ${ }^{5}$ Faculty of Plantation and Agrotechnology, Universiti \\ Teknologi Mara Perlis, 02600 Arau, Perlis, MALAYSIA
}

${ }^{6,7}$ Faculty of Science and Technology, Universiti Kebangsaan Malaysia, MALAYSIA

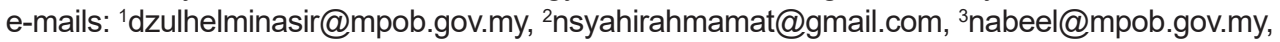

${ }^{4}$ meilina@mpob.gov.my, ${ }^{5}$ nurulfatihahabdlatip@uitm.edu.my, ${ }^{6}$ suriyanti@ukm.edu.my,

7*izfahazmi@ukm.edu.my

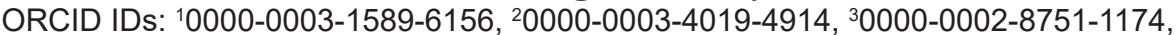

${ }^{4} 0000-0003-4825-5021,{ }^{5} 0000-0002-7171-5607,{ }^{6} 0000-0002-3450-3867$,

${ }^{7 *} 0000-0003-0933-7083$

\section{ABSTRACT}

The pollinating weevil, Elaeidobius kamerunicus was introduced to Malaysia as an oil palm pollinator agent in 1981. After the introduction, the weevil has distributed widely in the oil palm plantation around Malaysia. This study aims to investigate the morphometric differences in Elaeidobius kamerunicus population within Malaysia, as well as from its originating country, Cameroon. A total of 540 weevils were collected from eight localities in Malaysia, and 60 from Cameroon, Africa. The five morphological measurements were taken ie. total body length (TL), elytra length $(E L)$, pronotum length (PL), body width (BW) and the snout length (SL) using the Portable Capture Pro v2.1 Dinolite. The one-way ANOVA indicated significant differences amongst the five morphological characteristics between the weevil populations for both males and females from the eight localities $(P<0.05)$, respectively. For the male and female populations at different localities, the Principal Component Analysis explained $79.0 \%$ and $76.6 \%$, respectively. Moreover, the Canonical Discriminant Function explained $95.5 \%$ and $90.2 \%$ of the variance for male and female population, respectively. Both the result of PCA and CDA conducted showed little variation between the eight localities for male and female weevil populations in Malaysia respectively. This study showed slight differences in morphometric characters for the weevil population in Malaysia.

Key words: Elaeis guineensis, Elaeidobius kamerunicus, principal component analysis, canonical discriminant analysis, morphological characters.

Muhammad Nasir, D., Mamat, N.-S., Abdul Muneim, N.A., Ong-Abdullah, M., Abd Latip, N.-F., Su, S., \& Hazmi, I.R. (2020). Morphometric analysis of the oil palm pollinating weevil, Elaeidobius kamerunicus (Faust, 1878) (Coleoptera: Curculionidae) from oil palm plantations in Malaysia. Journal of the Entomological Research Society, 22(3), 275-291. 


\section{INTRODUCTION}

The oil palm, Elaeis guineensis (Arecales: Arecaceae), a monoecious plant that contains both male and female flowers on a single tree is one of the most extensively cultivated plantation crops in many parts of the world (Sambathkumar \& Ranjith, 2011). Elaeis guineensis are known to be most important industrial crop in Malaysia. It originated from West Africa and being introduced to Malaysia as landscape plants in early 19 centuries. Then, oil palm has become as one of the most importance industrial crop and powered the economic growth of Malaysia. Today, approximately 5.9 million hectares of land in Malaysia is under oil palm cultivation; producing 19.86 million tonnes of palm oil and 2.32 tonnes of palm kernel oil (Parvez et al., 2020). Malaysia is one the largest producers and exporters of palm oil in the world, accounting for $11 \%$ of the world's oils \& fats production and $27 \%$ of export trade of oils \& fats (Malaysian Palm Oil Council).

Until the late 1970s, due to poor yield and fruit developments, hand-pollination or assisted pollination had to be carried out by most plantations, especially for younger palms (Hussein, Lajis, \& Ali, 1991). In the early 1980s, the oil palm pollinating weevil, Elaeidobius kamerunicus (Coleoptera: Curculionidae), was introduced into the plantations to overcome the problem of inconsistencies in oil palm pollination (Syed, Law, \& Corley, 1982). It is well known as one of the main pollinating insects in oil palm plantations.

Elaeidobius kamerunicus has an important role in pollinating oil palm plants. Pollination occurs because this beetle is attracted by the scent of flowers, especially male flowers that are stronger in aroma than female flowers. When perched on male flowers, pollen will stick to his body. Then when perched on a receptive (blooming) female flower, pollen will be released from the beetle and pollinate female flowers (Setyamidjaja, 2006). In addition, this beetle is harmless and does not damage other plants, because this beetle can only eat and reproduce in oil palm male flowers (Syed, 1982). The study by Luqman et al. (2018) reported that the abundance of $E$. kamerunicus are highest in the oil palm plantation due to the presence of more male flowers of oil palm where they live, feed and breed as they are highly dependent on them.

Through its introduction, oil palm pollination significantly improved resulting in better fruit set levels and oil extraction ratios and hence increased yields (Caudwell, Hunt, Reid, \& Mensah, 2003). The introduction of the oil palm pollinating weevil into Malaysia has saved the industry an estimated US $\$ 60$ million annually, mostly due to the discontinuation of assisted pollination practices (Hussein et al, 1991; Caudwell et al, 2003). However, there has been a growing concern regarding the periodic occurrence of poor pollination and yield loss in certain Malaysian oil palm plantations (Teo, 2015). In several areas in Indonesia, the fruit set formation was so poor that they had to reintroduce the assisted pollination program as a solution (Prasetyo, Arif, \& Hidayat, 2012; Prasetyo, 2013). Factors that could contribute to these problems are, (1) poor pollination activity due to the low weevil population (Prasetyo, Purba, \& Susanto, 2014) (2) inbreeding depression (3) parasitism by female nematode Elaeolenchus 
parthenonema (Nematoda: Anandranematidae) (Rao \& Law, 1998; Poinar, Jackson, Bell, \& Wahid, 2002) (4) changing diets of predators favoring to prey on oil palm pollinating weevil (Muhammad-Luqman, Izfa-Riza, Idris, \& Dzulhelmi, 2017) and (5) weather change (Dhileepan, 1994; Prasetyo, Supriyanto, Susanto, \& Purba, 2010; Melendez \& Ponce, 2016). According to Nurul Fatihah et al., (2019), the amount of rainfall was found to positively correlate with the E. kamerunicus population.

The oil palm pollinating weevil is dark brown to black and small with the average length size of the adult weevil is between 1.8 to $4.0 \mathrm{~mm}$ (O'Brien \& Woodruff, 1986). Males have short rostrum, are hairier, having wing cases with small tubercles and are generally larger (3-4 mm), while the females have longer rostrum, less hair, absence of small tubercles on wing cases and smaller in size $(2-3 \mathrm{~mm}$ ) (Aisagbonhi et al, 2004; Kurniawan, 2010; Ayuningsih, 2013). The duration for the oil palm pollinating weevil to develop from an egg to larva I stage, followed by larva II, then larva III before forming a pupa, then becoming an adult, covers 10-25 days and the life span of the weevil is between 15-17 days (Syed et al, 1982; Herlinda, Pujiastuti, Adam, \& Thalib, 2006; Meliala, 2008; Tuo, Koua, \& Hala, 2011). According to Fitraini, Bakti, Prasetyo, \& Rozziansha (2018), the span for the egg to develop into larva I took about two days, to larval II about two days, to larval III about five days, and from larval III to adults in two days, while the adult took about 10-14 days for living.

Morphometric measurements in insects are important tools to evaluate variations because the exoskeleton can be easily measured and physical distortions rarely occur as in the soft parts of other animal groups (Thiago, Femanda, \& Marconi, 2011). The analysis of their shape and size should be one of the earliest parameters to be established before other factors are examined (Adams \& Rolhlf, 2000). A study by Siti-Nurlydia et al., (2018). successfully proved that Rhynchophorus vulneratus and $R$. ferrugineus are morphologically distinct species based on the morphometric study. For a commodity industry, monitoring one of the main oil palm pollinating weevils is extremely important, especially when its productivity relies on the ecological services provided by these insects. Slight differences in their morphometric characteristics are one of many indications on the possible effects of the local environmental conditions, climatic situation and gene pool on the weevils (Inward, Davies, Pergande, Denham, \& Vogler, 2011). This could further impact their life cycle, reproduction and general behavior (Den Boer, 1985; Matalin, 2007; Sukhodolskaya, 2016).

After more than 35 years from the first introduction of weevils in Malaysia, prolonged exposure to biotic and abiotic factors, different farming practices in various oil palm plantations may have directly and indirectly affected the morphological characteristics of the oil palm pollinating weevil (Nurul Fatihah et al., 2019). Therefore, in recent years, Nurul Fatihah et al., (2019) has conducted a study on the morphological difference of E. kamerunicus at three different locations (countries), namely Malaysia, Liberia, and Indonesia. The results by Nurul Fatihah et al., (2019) suggested that the separation of $E$. kamerunicus existed among the three different countries.

In consideration of the Malaysian population, this study aims to investigate the morphometric differences and variations among the weevil population in oil palm 
plantation around Malaysia, ie. Perlis, Pahang, Perak, Terengganu, Johor, Selangor, Sabah and Sarawak.

\section{MATERIAL AND METHODS}

Samples of weevils were collected from eight different oil palm plantations in Malaysia (Fig. 1), which planted with seed-derived commercial DxP materials, aged between seven to 12 years after planting. The E. kamerunicus samples are also collected from Cameroon Africa and treated as an outgroup (Table 1). The spikelets of fully anthesized flowers occupied by weevils were sampled.

Sixty $(60)$ weevils consisting of thirty males and thirty female individuals were taken from each population, respectively from the fully anthesized spikelet. Morphometric characters, treated as a variable was measured using portable capture digital microscope (portable capture Pro v2.1 Dinolite. The five variables measured were total body length (TL), elytra length (EL), pronotum length $(P L)$, body width (BW) and the snout length (SL) (Nurul-Fatihah et al., 2019). One-way ANOVA tests were calculated to determine the presence of significant difference amongst the five morphological characters between the male and female weevil populations from the eight localities in Malaysia. Following that, the male and female weevils were pooled while maintaining their morphological characters and localities. At-test was then run to determine whether there were significant differences between the five morphological characters, regardless of the sex of the weevils in Malaysia. Principal component analysis and canonical discriminant analysis were then applied to confirm if each of the weevil population from the eight localities forms distinct units. The analyses were done using the MINITAB version 17 for Principal Component Analysis (PCA) and SPSS version 12 to run Canonical Discriminant Analysis (CDA).

\section{RESULTS AND DISCUSSION}

A total of 540 weevils ( 270 males and 270 females) were successfully measured according to the five variables, ie TL: Total body length; EL: Elytra length; HL: Pronotum length; BW: Body width; SL: Snout length. The mean of each variable, the male and female for each location are presented in Table 2. The weevils' sample from Perlis showed the smallest in all the morphological characters while the largest was from the Johor population (Figs. 2-6). There was a significant difference in all measured characters amongst the weevil populations, both in male and female, from the different localities (One-way ANOVA; $P<0.05$ ) (Table 3).

Based on the sex of the weevil, there was a difference in the morphometric evaluation (Table 4). The morphological size variation between the male and female weevils was discernible merely on their appearance. This is following the report by Nurul Fatihah et al., (2019) which morphometric characters were significantly contributed to the separation of sexes in E. kamerunicus. 
Morphometric Analysis of the Oil Palm Pollinating Weevil, Elaeidobius kamerunicus

Morphometrical characters are influenced by the interaction between environmental conditions and the genetic population (Zahiri, Sarafrazi, Salehi, \& Kunkel, 2006). However, the previous study on insects with specific host plants showed that the phenotype of each individual was affected far more strongly by its host plant than by the genetic differences among populations (Wool \& Hales, 1997). In the case of the oil palm, the weevil populations exhibited many similarities in their morphological characters. The variation in the beetle's body form and size is highly likely to be related to the specific habitat demands on their physiological and behavioral characteristics (Den Boer, 1986). Intraspecific sexual dimorphism is a phenomenon widely distributed among animals (Fairbairn, 1997; Blanckenhorn, 2005). In many beetles, female tends to be much larger than male, a reason generally associated with the reproductive features where the dimorphism is conspicuous (Teder \& Tammaru, 2005), although there were no significant differences in body size between sexes (e.g. Ferreira, Pires, Guedes, Mendes, \& Coelho, 2006; Brygadyrenko \& Slynko, 2015). On the contrary, the male of the oil palm pollinating weevil is much larger than the female in body size except the snout length. The female weevils have longer snouts that could be associated with a better protrusion to assist in placing the eggs deeper into the inflorescence during the anthesis of the male flower.

To evaluate the existence of differences in the morphological characters of the weevil populations from the eight localities in Malaysia and Cameroon as an outgroup, multivariate examination, Principal Component Analysis (PCA) and Canonical Discriminate Analysis (CDA) were implemented. Canonical Discriminate Analysis is based on original variables extracted from linear combinations aimed at quantifying the relationship between categorical variables. Meanwhile, PCA aims at identifying and explaining the maximum number of variances in the multivariate hyperspace of the data set (Huntley, 2011; Sorbolini et al, 2016). Most of the total variance was accounted for the first two principal components analysis (PCA) for the score plot graph.

Based on PCA, four principal components were extracted, with the first two components accounting for most of the total variance. Moreover, the five variables were well represented in the first two principal components based on their loading values. Both the male and female weevil populations for Principal Component 1 (PC1) generally showed high positive loading values for all parameters (Table 5 and Table 6). The range of loading values for the male weevil population is between 0.022 to 0.819 with the highest eigenvalue of 2.846 and explained by $57.0 \%$ variation as the main contributor. Principal Component 2 (PC2) accounted for only $22.1 \%$ of the variance, with an eigenvalue of 1.103 . Based on the two extracted principal components, a total cumulative variation of $79.1 \%$ was achieved (Table 5). The female weevil population showed a similar trend, whereby the Principal Component 1 (PC1) with a range of loading values from 0.009 to 0.807 resulted in the highest eigenvalue at 2.967 associated with a 59.3\% total variation. Principal Component 2 (PC2) had an eigenvalue of 0.862 accounting for only $17.2 \%$ of the variance. Based on the extracted principal components, a cumulative variation at $76.6 \%$ was achieved (Table 6). 
The scatter plot showed that male weevil populations within the eight localities from Malaysia clustered together but formed a distinct cluster with weevils from Cameroon (Fig. 7). Meanwhile, non-distinguishable clusters were observed with the female weevil populations (Fig. 8).

Based on CDA, five canonical functions were extracted. For the male weevil populations, Canonical Discriminant 1 (CD1) had an eigenvalue of 3.918 with the range of loading values between 0.046 to 9.155 accounting for $86.6 \%$ of the variance, while Canonical Discriminant (CD2) with an eigenvalue of 0.400 accounted for $8.9 \%$. The two canonical discriminants explained by $95.5 \%$ of the total variance (Table 7 ).

The scatter plot generated between CD1 and CD2 revealed a clear separation between the male weevil populations from Malaysia and Cameroon in Africa (Fig. 9). For the female weevils, the Canonical Discriminant 1 (CD1) had an eigenvalue of 2.927 , accounting for $69.9 \%$ of the variance, while Canonical Discriminant 2 (CD2) with an eigenvalue of 0.851 represented $20.3 \%$ of the total variance. The two canonical discriminants together covered $90.2 \%$ of the total variance (Table 8 ). The scatter plot of the female weevil populations based on the component scores showed clear clustering between the populations from Malaysia and Cameroon (Fig. 10).

In this study, both the result of PCA and CDA conducted showed little variation between the eight localities for male and female weevil populations in Malaysia respectively. Weevil population from Cameroon, Africa was treated as an outgroup and was distinctly separated from the weevil populations in Malaysia. The properties of soil, plant cover and anthropogenic impact in ecosystems are some factors that may influence the morphology in ground beetles (Blake, Foster, Eyre, \& Luff, 1994; Giglio, Giulianini, Zetto, \& Talarico, 2011; Sukhodolskaya, 2013). However, there was no indication of soil properties or palm age to have affected the weevil size as shown in the weevil population. This shows healthy traits and that the morphological characters are stable (Schluter, 2000; Schauble, 2004).

\section{CONCLUSIONS}

The present study allows morphometric characters of male and female weevil populations to be evaluated, to reveal their reaction towards the present condition in oil palm plantations. It is evident that there is very little variation in the body size of the weevils between the different localities in Malaysia, however, a distinct separation is observed with the weevil population from Cameroon, Africa. This is an indication that the weevil population in Malaysia exhibit slight differences in their morphological characters. Future studies should focus on management practices and other possible biotic factors (ie. parasitism, nematode infestation) that may lead to body size variation. 
Morphometric Analysis of the Oil Palm Pollinating Weevil, Elaeidobius kamerunicus

Table 1. Sampling locations in Malaysia.

\begin{tabular}{|c|l|l|l|}
\hline & Localities & GPS Coordinates & Soil type \\
\hline & Malaysia & & \\
\hline L1 & FELDA Chuping 2, Perlis & $6^{\circ} 30^{\prime} 14^{\prime \prime} \mathrm{N}, 100^{\circ} 11^{\prime} 50^{\prime \prime} \mathrm{E}$ & Mineral \\
\hline L2 & FELDA Jerantut, Pahang & $4^{\circ} 21^{\prime} 22^{\prime \prime} \mathrm{N}, 12^{\circ} 23^{\prime} 34^{\prime \prime} \mathrm{E}$ & Mineral \\
\hline L3 & MPOB Teluk Intan, Perak & $4^{\circ} 02^{\prime} 51^{\prime \prime} \mathrm{N}, 101^{\circ} 01^{\prime} 08^{\prime \prime} \mathrm{E}$ & $\begin{array}{l}\text { Shallow } \\
\text { peat }\end{array}$ \\
\hline L4 & $\begin{array}{l}\text { MPOB Hulu Paka, } \\
\text { Terengganu }\end{array}$ & $4^{\circ} 33^{\prime} 14^{\prime \prime} \mathrm{N}, 103^{\circ} 11^{\prime} 16^{\prime \prime} \mathrm{E}$ & Mineral \\
\hline L5 & Yong Peng, Johor & $2^{\circ} 04^{\prime} 11^{\prime \prime} \mathrm{N}, 103^{\circ} 04^{\prime} 09^{\prime \prime} \mathrm{E}$ & Mineral \\
\hline L6 & UPM Plantation, Selangor & $2^{\circ} 59^{\prime} 45^{\prime \prime} \mathrm{N}, 101^{\circ} 42^{\prime} 56^{\prime \prime} \mathrm{E}$ & Mineral \\
\hline L7 & MPOB Lahad Datu, Sabah & $5^{\circ} 06^{\prime} 12^{\prime \prime} \mathrm{N}, 118^{\circ} 37^{\prime} 05^{\prime \prime} \mathrm{E}$ & Mineral \\
\hline L8 & MPOB Sessang, Sarawak & $1^{\circ} 55^{\prime} 35^{\prime \prime} \mathrm{N}, 111^{\circ} 13^{\prime} 32^{\prime \prime} \mathrm{E}$ & Deep peat \\
\hline & & & \\
\hline & Africa & & \\
\hline & Cameroon, West Africa & $7^{\circ} 22^{\prime} 11^{\prime \prime} \mathrm{N}, 12^{\circ} 20^{\prime} 41^{\prime \prime} \mathrm{E}$ & Kaolisols \\
\hline
\end{tabular}

Table 2. The average values in millimeters (mean \pm standard deviation) of the morphometric characters of male and female weevils in eight different localities in Malaysia and one locality from Africa.

\begin{tabular}{|c|c|c|c|c|c|c|c|c|c|c|}
\hline State & \multicolumn{2}{|c|}{ Perlis } & \multicolumn{2}{|c|}{ Pahang } & \multicolumn{2}{|c|}{ Perak } & \multicolumn{2}{|c|}{ Terengganu } & \multicolumn{2}{|c|}{ Johor } \\
\hline Gender & 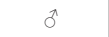 & 우 & $\delta$ & 우 & $\delta$ & 우 & $\delta$ & 우 & $\sigma$ & 우 \\
\hline TL & $2.62 \pm 0.32$ & $2.46 \pm 0.16$ & $3.07 \pm 0.38$ & $2.70 \pm 0.17$ & $3.28 \pm 0.38$ & $2.92 \pm 0.20$ & $3.05 \pm 0.25$ & $2.56 \pm 0.19$ & $3.45 \pm 0.38$ & $3.03 \pm 0.20$ \\
\hline EL & $1.75 \pm 0.24$ & $1.62 \pm 0.13$ & $2.09 \pm 0.30$ & $1.81 \pm 0.13$ & $2.24 \pm 0.32$ & $1.94 \pm 0.17$ & $2.11 \pm 0.14$ & $1.80 \pm 0.16$ & $2.43 \pm 0.30$ & $2.11 \pm 0.16$ \\
\hline $\mathrm{PL}$ & $0.63 \pm 0.12$ & $0.65 \pm 0.10$ & $0.74 \pm 0.13$ & $0.69 \pm 0.11$ & $0.80 \pm 0.13$ & $0.78 \pm 0.08$ & $0.69 \pm 0.26$ & $0.60 \pm 0.13$ & $0.77 \pm 0.17$ & $0.72 \pm 0.12$ \\
\hline BW & $0.81 \pm 0.07$ & $0.77 \pm 0.08$ & $0.93 \pm 0.09$ & $0.82 \pm 0.07$ & $1.00 \pm 0.08$ & $0.91 \pm 0.06$ & $1.11 \pm 0.12$ & $0.99 \pm 0.13$ & $1.12 \pm 0.14$ & $0.98 \pm 0.08$ \\
\hline SL & $0.76 \pm 0.12$ & $1.01 \pm 0.06$ & $0.81 \pm 0.13$ & $1.15 \pm 0.08$ & $0.80 \pm 0.12$ & $1.19 \pm 0.07$ & $0.89 \pm 0.13$ & $1.10 \pm 0.16$ & $0.84 \pm 0.11$ & $1.21 \pm 0.09$ \\
\hline State & Sela & goor & & oah & Sar & wak & Cam & roon & & \\
\hline Gender & $\delta$ & 우 & $\hat{\sigma}$ & 우 & $\delta$ & 우 & $\delta$ & 우 & & \\
\hline TL & $3.22 \pm 0.36$ & $2.84 \pm 0.16$ & $3.06 \pm 0.39$ & $2.82 \pm 0.22$ & $3.38 \pm 0.21$ & $2.94 \pm 0.20$ & $3.60 \pm 0.18$ & $2.92 \pm 0.14$ & & \\
\hline $\mathrm{EL}$ & $2.11 \pm 0.32$ & $1.85 \pm 0.10$ & $2.12 \pm 0.31$ & $1.92 \pm 0.15$ & $2.35 \pm 0.21$ & $1.93 \pm 0.13$ & $2.57 \pm 0.18$ & $2.02 \pm 0.09$ & & \\
\hline PL & $0.86 \pm 0.21$ & $0.78 \pm 0.11$ & $0.69 \pm 0.13$ & $2.01 \pm 0.15$ & $0.78 \pm 0.17$ & $0.81 \pm 0.12$ & $0.82 \pm 0.07$ & $0.80 \pm 0.18$ & & \\
\hline BW & $1.07 \pm 0.13$ & $0.92 \pm 0.08$ & $1.05 \pm 0.17$ & $0.93 \pm 0.12$ & $1.04 \pm 0.11$ & $0.89 \pm 0.08$ & $1.51 \pm 0.06$ & $1.26 \pm 0.05$ & & \\
\hline SL & $0.81 \pm 0.13$ & $1.20 \pm 0.11$ & $0.77 \pm 0.10$ & $1.10 \pm 0.10$ & $0.73 \pm 0.09$ & $1.09 \pm 0.14$ & $1.09 \pm 0.11$ & $1.30 \pm 0.08$ & & \\
\hline
\end{tabular}

TL: Total body length; EL: Elytra length; HL: Pronotum length; BW: Body width; SL: Snout length. 


$$
\text { MUHAMMAD NASIR, D., MAMAT, N.-S., ABDUL MUNEIM, N.A., et al. }
$$

Table 3. One-way ANOVA between localities and sex of weevils with each of five morphological variables in Malaysia. Significant differences were only shown for morphological characters for male and female weevil populations between the eight localities in Malaysia respectively.

\begin{tabular}{|c|c|c|c|c|c|c|c|c|c|c|}
\hline Variables & \multicolumn{5}{|c|}{ Male } & \multicolumn{5}{|c|}{ Female } \\
\hline & $\mathrm{df}$ & $\mathrm{SS}$ & $\mathrm{MS}$ & $\mathrm{F}$ & $\mathrm{P}$ & $\mathrm{df}$ & $\mathrm{SS}$ & $\mathrm{MS}$ & $\mathrm{F}$ & $\mathrm{P}$ \\
\hline $\mathrm{TL}$ & 7 & 13.9 & 1.986 & 17.08 & $\mathrm{P}<0.0001$ & 7 & 7.38 & 1.054 & 29.42 & $\mathrm{P}<0.0001$ \\
\hline $\mathrm{EL}$ & 7 & 8.90 & 1.271 & 17.00 & $\mathrm{P}<0.0001$ & 7 & 4.19 & 0.598 & 29.39 & $\mathrm{P}<0.0001$ \\
\hline $\mathrm{PL}$ & 7 & 1.10 & 0.157 & 5.34 & $\mathrm{P}<0.0001$ & 7 & 1.07 & 0.153 & 12.50 & $\mathrm{P}<0.0001$ \\
\hline $\mathrm{BW}$ & 7 & 2.22 & 0.32 & 23.32 & $\mathrm{P}<0.0001$ & 7 & 1.01 & 0.14 & 12.89 & $\mathrm{P}<0.0001$ \\
\hline $\mathrm{SL}$ & 7 & 0.53 & 0.075 & 5.63 & $\mathrm{P}<0.0001$ & 7 & 1.17 & 0.167 & 20.96 & $\mathrm{P}<0.0001$ \\
\hline
\end{tabular}

TL: Total body length; EL: Elytra length; PL: Pronotum length; BW: Body width; SL: Snout length.

Table 4. Comparison on morphological variables between male and female weevils using t-test.

\begin{tabular}{|l|c|c|c|}
\hline \multicolumn{1}{|c|}{ Variables } & t & df & P-value \\
\hline Total body length & 11.26 & 398.9 & $<0.0001$ \\
\hline Elytra length & 11.13 & 384.5 & $<0.0001$ \\
\hline Body width & 1.98 & 429.6 & 0.0489 \\
\hline Pronotum length & 29.17 & 478.0 & $<0.0001$ \\
\hline Snout length & 9.61 & 442.9 & $<0.0001$ \\
\hline
\end{tabular}

Table 5. Coefficient component principal of male weevils using Principal Component (PC) analysis.

\begin{tabular}{|l|c|c|c|c|}
\hline Parameter & PC1 & PC2 & PC3 & PC4 \\
\hline TL & 0.562 & -0.241 & 0.118 & -0.267 \\
\hline EL & 0.520 & -0.044 & 0.524 & -0.296 \\
\hline PL & 0.354 & -0.459 & -0.754 & -0.019 \\
\hline BW & 0.490 & 0.298 & 0.022 & 0.819 \\
\hline S & 0.219 & 0.800 & -0.376 & -0.412 \\
\hline Eigenvalue & 2.8475 & 1.1026 & 0.7199 & 0.3264 \\
\hline \% Variation & 57.0 & 22.1 & 14.4 & 6.5 \\
\hline \% Cumulative Variation & 57.0 & 79.0 & 93.4 & 99.9 \\
\hline
\end{tabular}


Morphometric Analysis of the Oil Palm Pollinating Weevil, Elaeidobius kamerunicus

Table 6. Coefficient component principal of female weevils using Principal Component (PC) analysis.

\begin{tabular}{|l|c|c|c|c|}
\hline Parameter & PC1 & PC2 & PC3 & PC4 \\
\hline TL & 0.540 & -0.215 & -0.356 & 0.009 \\
\hline EL & 0.498 & 0.212 & -0.594 & 0.021 \\
\hline PL & 0.351 & -0.807 & 0.339 & 0.018 \\
\hline BW & 0.407 & 0.378 & 0.470 & 0.685 \\
\hline S & 0.413 & 0.339 & 0.430 & -0.728 \\
\hline Eigenvalue & 2.9669 & 0.8616 & 0.6017 & 0.5358 \\
\hline \% Variation & 59.3 & 17.2 & 12.0 & 10.7 \\
\hline \% Cumulative Variation & 59.3 & 76.6 & 86.6 & 99.3 \\
\hline
\end{tabular}

Table 7. Coefficient component principal of male weevils using Canonical Discriminant (CD) analysis.

\begin{tabular}{|l|c|c|c|c|c|}
\hline Parameter & CD1 & CD2 & CD3 & CD4 & CD5 \\
\hline TL & -1.991 & 1.922 & -1.837 & -1.872 & -9.155 \\
\hline EL & 0.860 & -0.598 & 1.790 & 0.493 & 4.554 \\
\hline PL & 1.572 & -0.592 & 1.410 & 2.108 & 7.415 \\
\hline BW & 0.935 & -0.283 & -0.393 & -0.526 & -0.046 \\
\hline S & 0.536 & -0.202 & 0.513 & 0.558 & -0.350 \\
\hline Eigenvalue & 3.918 & 0.400 & 0.102 & 0.075 & 0.029 \\
\hline \% Variation & 86.6 & 8.9 & 2.3 & 1.7 & 0.6 \\
\hline \% Cumulative Variation & 86.6 & 95.5 & 97.7 & 99.4 & 100.0 \\
\hline Canonical Correlation & 0.893 & 0.535 & 0.304 & 0.264 & 0.167 \\
\hline
\end{tabular}

Table 8. Coefficient component principal of female weevils using Canonical Discriminant (CD) analysis.

\begin{tabular}{|l|c|c|c|c|c|}
\hline Parameter & CDA1 & CDA2 & CDA3 & CDA4 & CDA5 \\
\hline TL & -0.865 & 0.847 & 0.371 & -0.371 & -2.761 \\
\hline EL & 0.228 & -0.003 & 0.426 & -0.442 & 1.693 \\
\hline PL & 0.500 & 0.284 & -0.919 & 0.321 & 2.205 \\
\hline BW & 1.022 & -0.355 & -0.084 & -0.272 & -0.169 \\
\hline S & 0.302 & 0.070 & 0.669 & 0.775 & -0.032 \\
\hline Eigenvalue & 2.927 & 0.851 & 0.270 & 0.133 & 0.008 \\
\hline \% Variation & 69.9 & 20.3 & 6.5 & 3.2 & 0.2 \\
\hline \% Cumulative Variation & 69.9 & 90.2 & 96.7 & 99.8 & 100.0 \\
\hline Canonical Correlation & 0.863 & 0.678 & 0.461 & 0.342 & 0.086 \\
\hline
\end{tabular}


MUHAMMAD NASIR, D., MAMAT, N.-S., ABDUL MUNEIM, N.A., et al.

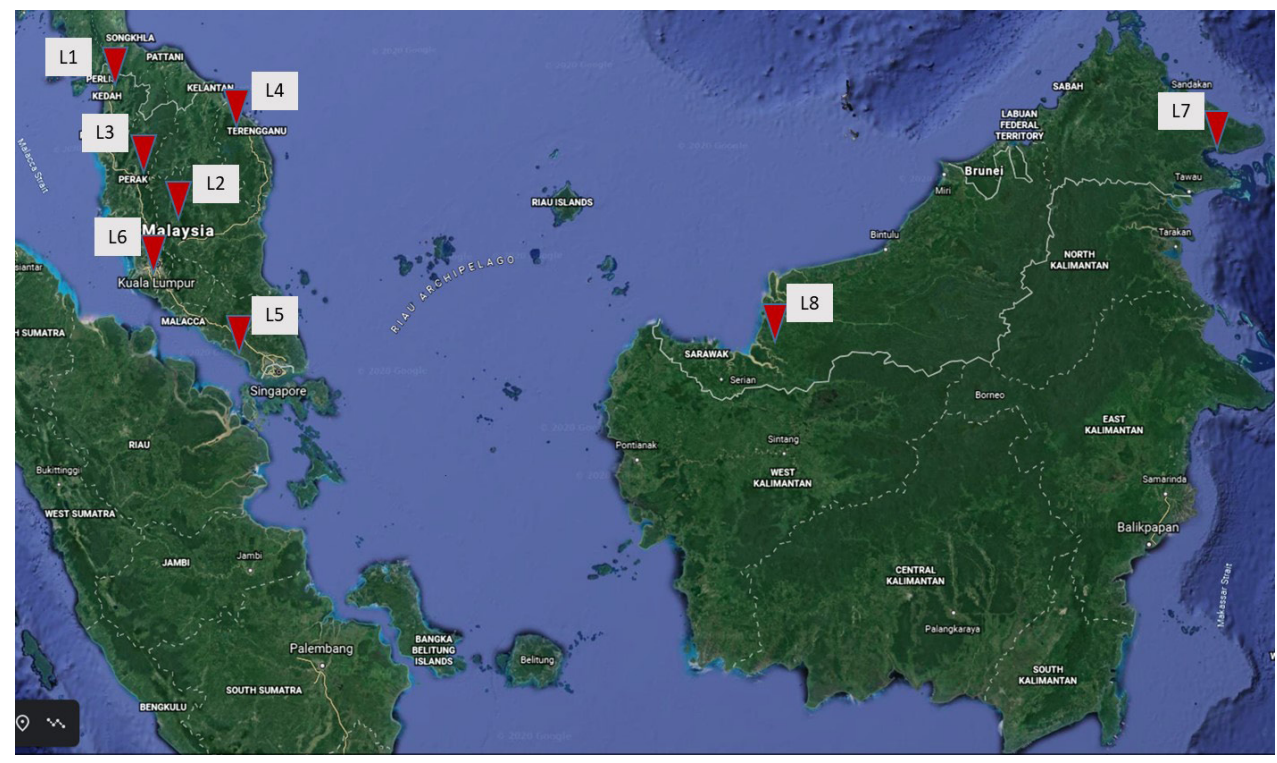

Fig. 1. Eight sampling locality located in Malaysia.

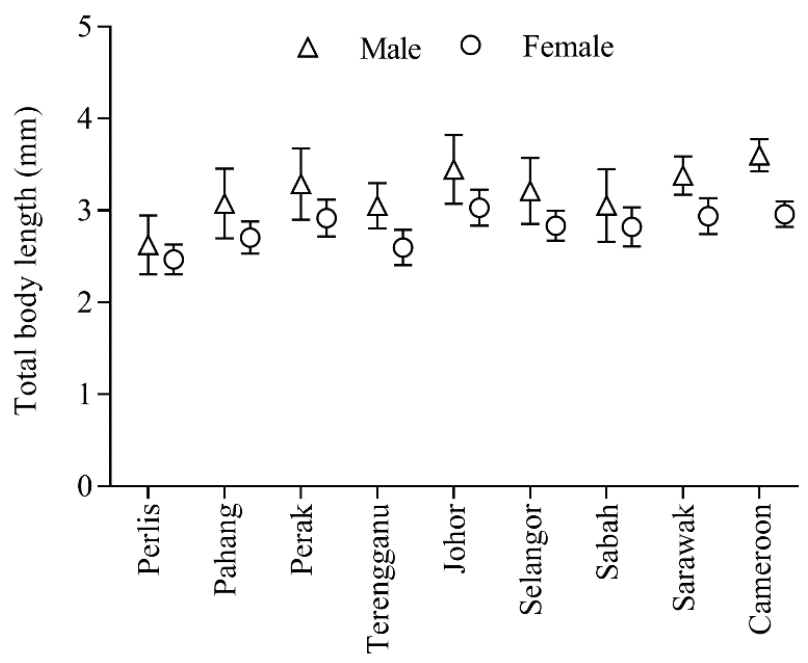

Localities

Fig. 2. Mean and standard deviation on total body length of the male and female weevil populations in eight different localities. 
Morphometric Analysis of the Oil Palm Pollinating Weevil, Elaeidobius kamerunicus

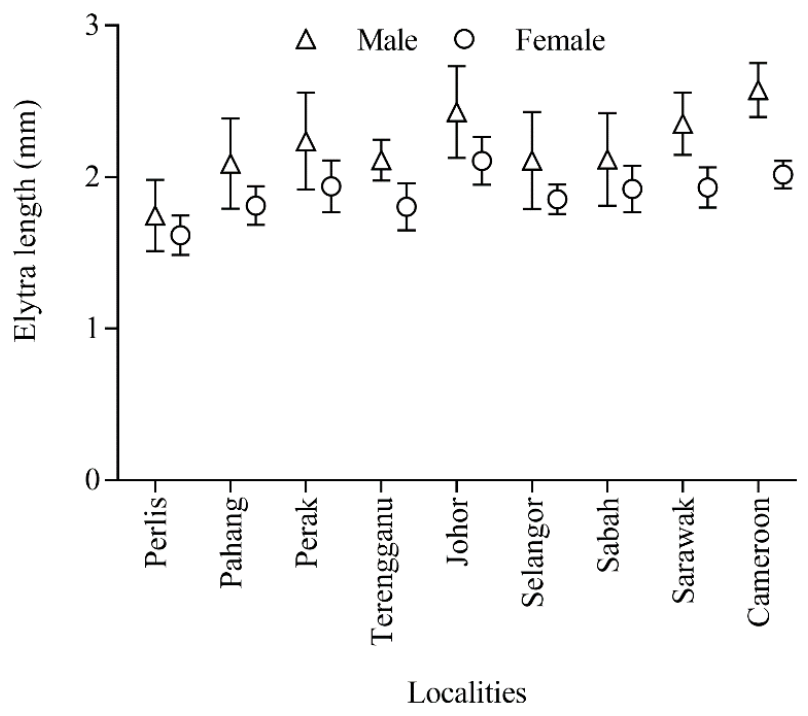

Fig. 3. Mean and standard deviation on elytra length of the male and female weevil populations in eight different localities.

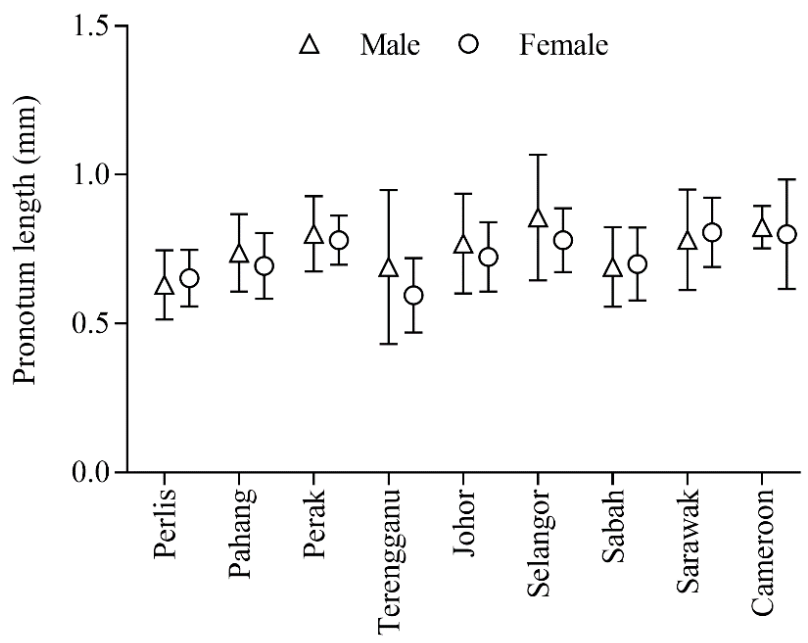

Localities

Fig. 4. Mean and standard deviation on pronotum length of the male and female weevil populations in eight different localities. 


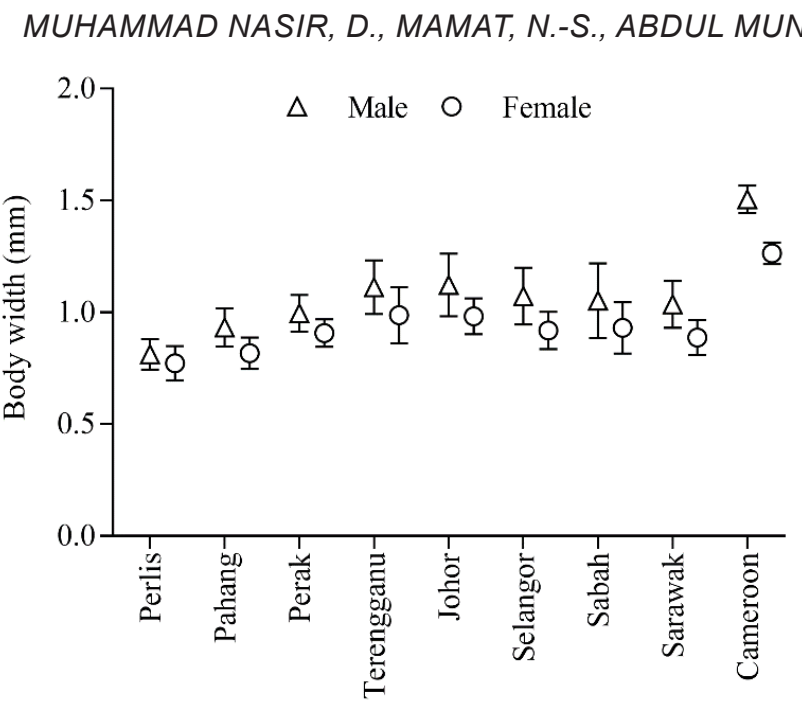

Localities

Fig. 5. Mean and standard deviation on body width of the male and female weevil populations in eight different localities.

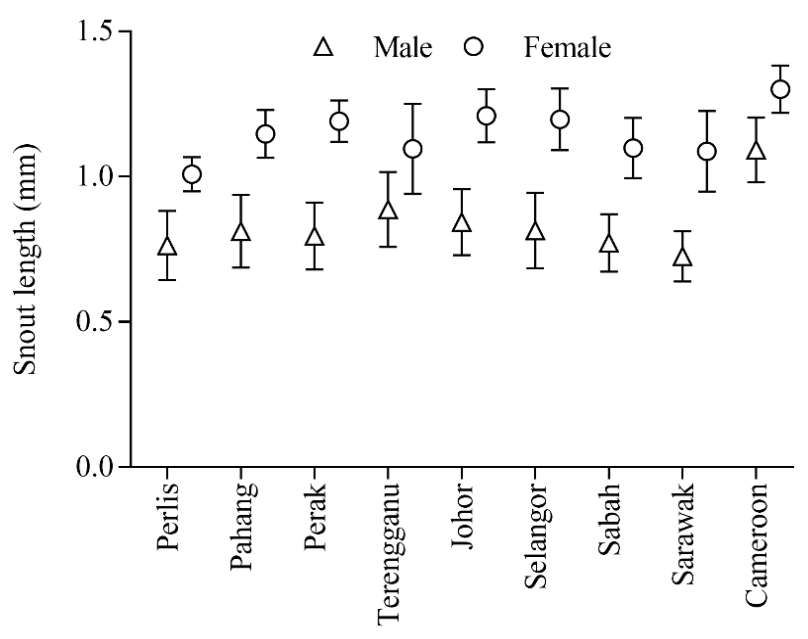

Localities

Fig. 6. Mean and standard deviation on snout length of the male and female weevil populations in eight different localities in Malaysia and one locality in Africa. 
Morphometric Analysis of the Oil Palm Pollinating Weevil, Elaeidobius kamerunicus

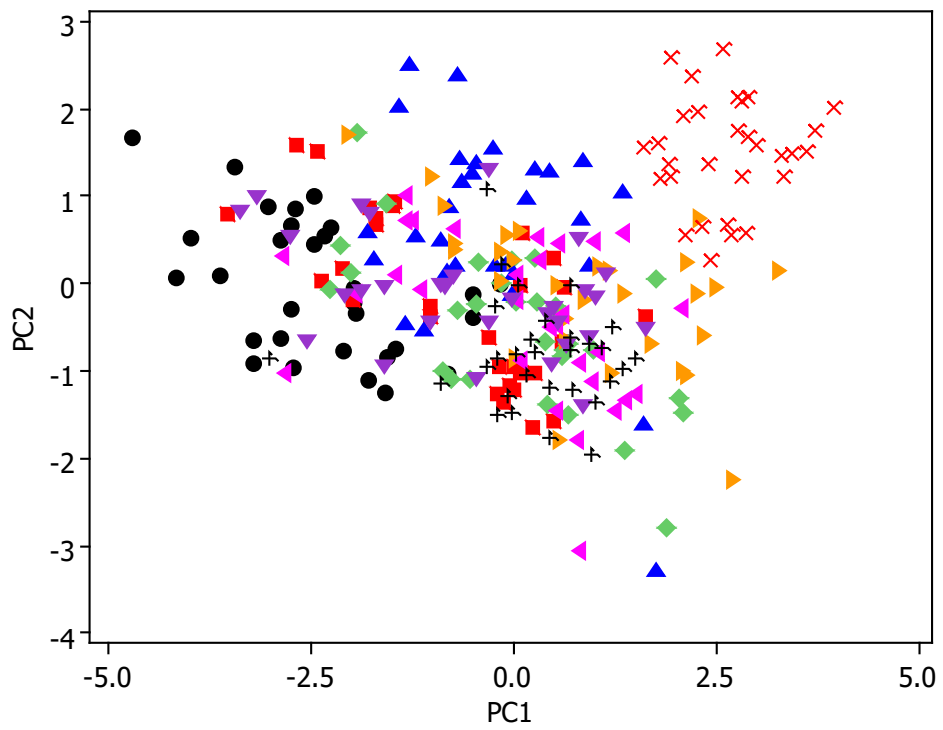

\begin{tabular}{|c|c|}
\hline & STATES \\
\hline & Perlis \\
\hline . & Pahang \\
\hline 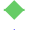 & Perak \\
\hline $\mathbf{A}$ & Terengganu \\
\hline$>$ & Johor \\
\hline 4 & Selangor \\
\hline$\nabla$ & Sabah \\
\hline+ & Sarawak \\
\hline$x$ & Cameron \\
\hline
\end{tabular}

Fig. 7. Scatter plot based on the Principal Component Analysis of Principal Component 1 against Principal Component 2 for male weevil population at eight localities in Malaysia and one locality in Africa.

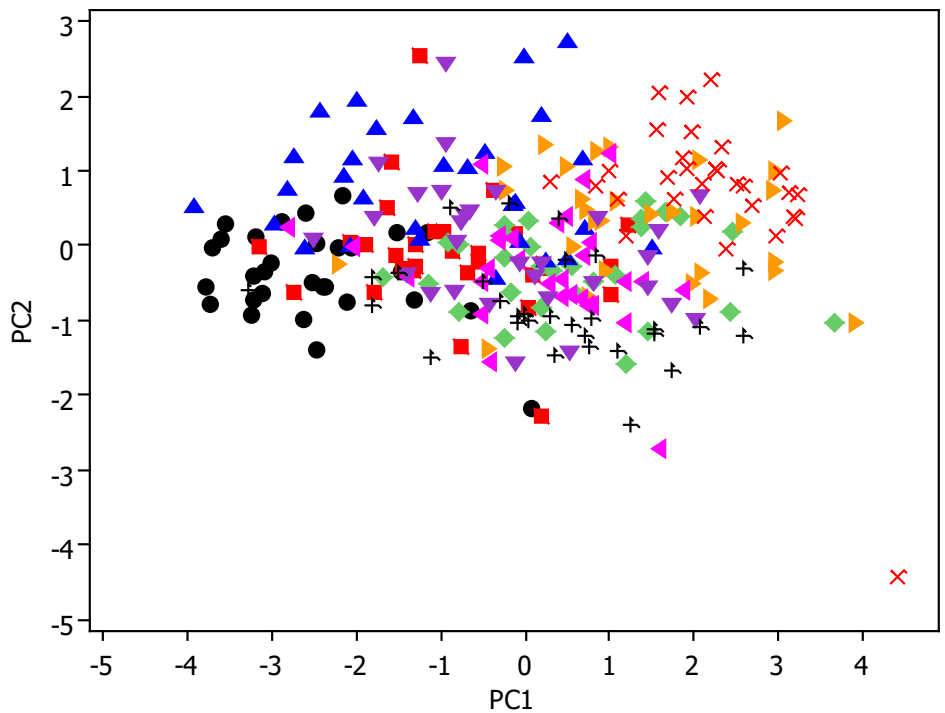

Fig. 8. Scatter plot based on the Principal Component Analysis of Principal Component 1 against Principal Component 2 for female weevil population at eight localities in Malaysia and one locality in Africa. 
MUHAMMAD NASIR, D., MAMAT, N.-S., ABDUL MUNEIM, N.A., et al.

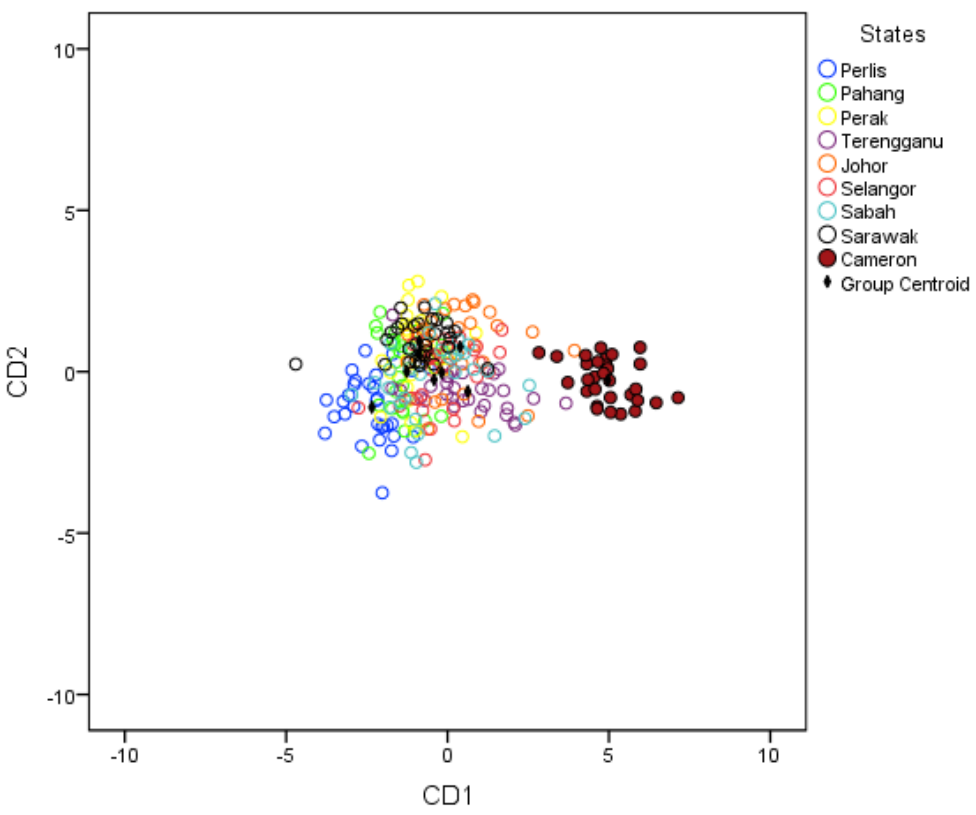

Fig. 9. Scatter plot based on the Canonical Discriminant analysis of Canonical Discriminant 1 against Canonical Discriminant 2 for male weevil population at eight localities in Malaysia and one locality in Africa.

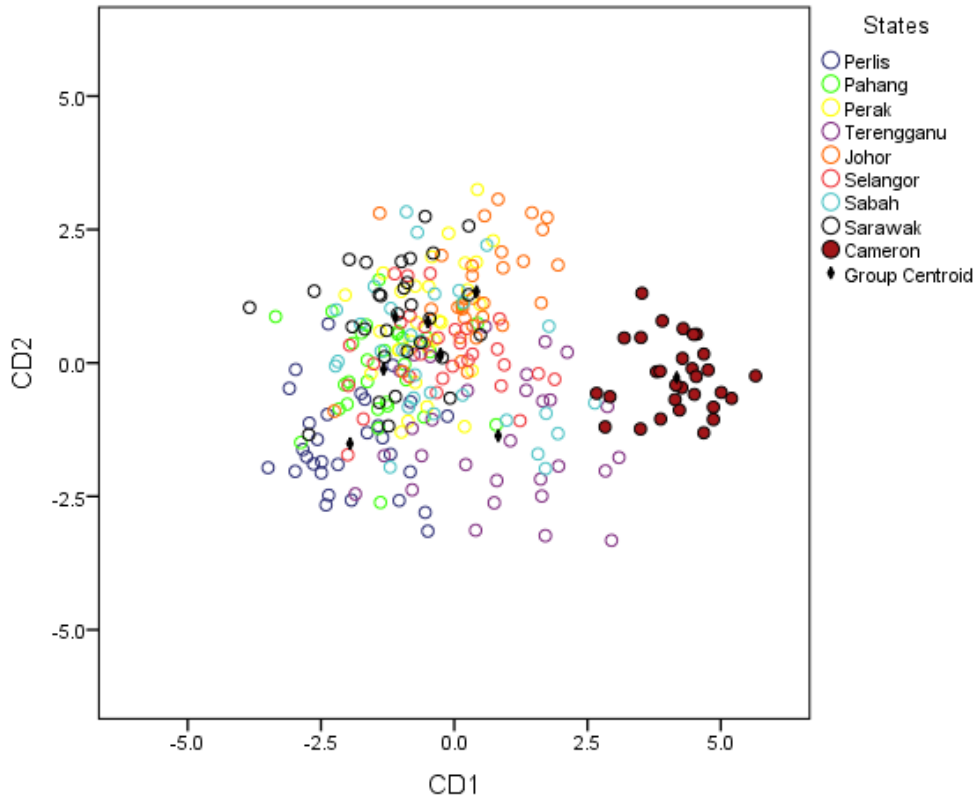

Fig. 10. Scatter plot based on the Canonical Discriminant analysis of Canonical Discriminant 1 against Canonical Discriminant 2 for female weevil population at eight localities in Malaysia and one locality in Africa. 
Morphometric Analysis of the Oil Palm Pollinating Weevil, Elaeidobius kamerunicus

\section{ACKNOWLEDGEMENT}

We acknowledged Luqman Hakim Azhari, Syahirah Zoilani, Muhammad Nurul Yaqin Syarif, Saharul Abillah Mohamad, Mohamad Rosman Sulaiman and Fabien Tengoua for their assistance in sample collection. We thank those who have directly and indirectly contributed to this article.

\section{REFERENCES}

Adams, D.C. \& Rolhf, F.J. (2000). Ecological character displacement in plethodon: biomechanical differences found from geometric morphological study. Proceedings of the Natural Academy of Sciences, USA, 97, 4106-4111.

Aisagbonhi, C.I. Norman, K. Okwuagwu, C.O. Wahid, M.B. Jackson, T., \& Adaigbe, V. (2004). Preliminary observations on a field population of the oil palm-pollinating weevil Elaeidobius kamerunicus in Benin City, Nigeria. International Journal of Tropical Insect Science, 24(3), 255-259.

Ayuningsih, M. (2013). Frekuensi kunjungan Elaeidobius Kamerunicus Faust pada bunga betina dan efektivitasnya terhadap pembentukan buah kelapa sawit. Tesis, Institut Pertanian Bogor, Bogor.

Blake, S. Foster, G.N., Eyre, M.D., \& Luff, M.L. (1994). Effects of habitat type and grassland management practices on the body size distribution of carabid beetles. Pedobiologia, 38, 502-512.

Blanckenhorn, W.U. (2005). Behavioural causes and consequences of sexual size dimorphism. Ethology, 111, 977-1016.

Brygadyrenko, V.V. \& Slynko, V.O. (2015). Morphological variability of Bembidion Articulatum (Coleoptera, Carabidae) populations: linear dimensions depend on sex, while morphological indisces depend on ecosystems. International Journal of Applied Environmental Science, 10(1), 163-187.

Caudwell, R.W., Hunt, D., Reid, A., \& Mensah, B.A. (2003). Insect pollination of oil palm - an evaluation of the long-term viability and sustainability of Elaeidobius kamerunicus. The Planter, 79(923), 75-91.

Den Boer, P.J. (1985). Fluctuations on density and survival of carabid populations. Oecologia, 67, 322-330.

Den Boer, P.J. (1986). Carabids as objects of study. In P.J. den Boer (Ed.). Carabid beetles. their adaptations and dynamics. XVIIth International Congress of Entomology, Gustav Fischer, Stuttgart, Germany.

Dhileepan, K. (1994). Variation in populations of the introduced pollinating weevil (Elaeidobius kamerunicus) (Coleoptera: Curculionidae) and its impact on fruit set of oil palm (Elaeis guineensis) in India. Bulletin of Entomological Research, 84, 477-485.

Fairbairn, D.J. (1997). Allometry for sexual size dimorphism: pattern and process in the coevolution of body size in males and females. Annual Review of Ecology and Systematics, 28, 659-687.

Ferreira, P.S.F., Pires, E.M., Guedes, R.N.C., Mendes, M., \& Coelho, L.A. (2006). seasonal abundance and sexual variation in morphometric traits of Oxelytrum discicolle (Brulle, 1840) (Coleoptera: Siphidae) in a Brazilian Atlantic Forest. Biota Neotropica, 6(2), 1-7.

Fitraini, A.A., Bakti, D., Prasetyo, A.E., \& Rozziansha, T.A.P. (2018). Biologi serangga penyerbuk (Elaeidobius kamerunicus Faust) (Coleoptera: Curculionidae) pada tanaman kelapa sawit di daerah dataran tinggi. Jurnal Agroekoteknologi FP USU, 6(4), 885-891.

Giglio, A., Giulianini, P.G., Zetto, T., \& Talarico, F. (2011). Effects of the pesticide dimethoate on a non-target generalist carabid. Pterostichus melas italicus (Dejean, 1828) (Coleoptera: Carabidae). Italian Journal of Zoology, 78(4), 471-477.

Herlinda, S., Pujiastuti, Y., Adam, T., \& Thalib, R. (2006). Life cycle of pollinator beetle (Elaeidobius kamerunicus Faust.) (Coleoptera: Curculionidae) on male flower of oil palm (Elaeis guineensis Jacq.) in the laboratory. Agria, 3(1), 10-12.

Hussein, M.Y., Lajis, N.H., \& Ali, J.H. (1991). Biological and chemical factors associated with the successful introduction of Elaeidobius kamerunicus Faust, the oil palm pollinator in Malaysia. Acta Horticulturae $6^{\text {th }}$ International Symposium on Pollination, 288, 81-87. 
Huntley, J.W. (2011). Exploratory multivariate techniques and their utility for understanding ancient ecosystems. In M., Laflamme et al. (Eds.). Quantifying the evolution of early life, Topics in Geobiology, 36, 1-451.

Inward, D.J.G., Davies, R.G., Pergande, C., Denham, A.J., \& Vogler, A.P. (2011). Local and regional ecological morphology of dung beetle assemblages across four biogeographic regions. Journal of Biogeography, 38(9), 1668-1682.

Kurniawan, Y. (2010). Demografi dan populasi kumbang Elaeidobius kamerunicus Faust (Coleoptera: Curculionidae) sebagai penyerbuk kelapa sawit (Elaeis guinennsis Jacq). Tesis, Institut Pertanian Bogor, Bogor.

Luqman, H.A., Noor, Nasuha A.A., Dzulhelmi, M.N., Nurul Fatihah, A.L., Muhamad Fahmi, M.H., Teo, T.M., Idris., A.B., \& Izfa Riza, H. (2018). Diversity and composition of beetles (Order: Coleoptera) in three different ages of oil palms in Lekir oil palm plantation, Perak, Malaysia. Serangga, 23(1), 58-71.

Malaysian Palm Oil Council (MPOC). (2020, July 14). Malaysian palm oil industry. http://www.mpoc.org. my/Malaysian_Palm_Oil_Industry.aspx.

Matalin, A.V. (2007). Typology of the life cycles of ground beetles (Coleoptera, Carabidae) of the western Palearctic. Entomological Review, 87(8), 947-972.

Melendez, M.R \& Ponce, W.P. (2016). Pollination in the oil palms Elaeis guineensis, E. oleifera and their hybrids (OxG), in Tropical America. Pesquisa Agropecuária Tropical Goaiania, 46(1), 102-110.

Meliala, R.A.S. (2008). Studi biologi serangga penyerbuk kelapa sawit Elaeidobius kamerunicus Faust (Coleoptera: Curculionidae) Elaeis guineensis Jacq. di Laboratium. Tesis. Universitas Sumatera Utara, Medan.

Muhammad-Luqman, H.A., Izfa-Riza, H., Idris, A.B., \& Dzulhelmi, M.N. (2017). Potential natural predators for oil palm pollinating weevil Elaeidobius kamerunicus Faust, 1878 (Coleoptera: Curculionidae) in Malaysia. Serangga, 22(2), 239-252.

Nurul Fatihah, A.L., Idris, A.B., Izfa, R.H., Cik-Mohd Rizuan, Z.A., Dewi, S., Shahrakbah, Y., \& Dzulhelmi, M.N. (2019). Morphometric comparison of the oil palm pollinator Elaeidobius kamerunicus Faust (Coleoptera: Curculionidae) from Malaysia, Indonesia, and Liberia. The Coleopterists Bulletin, 73(3), 746-756.

Nurul Fatihah, A.L., Muhamad Fahmi, M.H., Luqman, H.A., Syarifah Nadiah, S.M.D., Teo, T.M., Izfa Riza, H., \& Idris, A.B. (2019). Effects of rainfall, number of male inflorescences and spikelets on the population abundance of Elaeidobius kamerunicus (Coleoptera: Curculionidae). Sains Malaysiana 48(1), 15-21.

O'Brien, C.W. \& Woodruff, R.E. (1986). First records in the united states and south america of the african oil palm weevils Elaeidobius subvittatus Faust and Elaeidobius kamerunicus Faust (Coleoptera: Curculionidae). Florida Department of Agriculture and Consumer Services, 330, 1-2.

Parveez, A.G.K., Elina, H., Loh, S.K., Ong-Abdullah, M., Kamalrudin, M.S., Zanal Bidin, M.N.I., Sundram, S., Zafarizal, A.A.H., \& Zainab, I. (2020). Oil palm economic performance in Malaysia and R\&D progress in 2019. Journal of Oil Palm Research, 32(2), 159-190.

Poinar, J.R., Go, Jackson, T.A., Bell, N.L., \& Wahid, M.B. (2002). Elaeolenchus parthenonema n.g., n. sp. (Nematoda: Sphaerularioidea: Anandranematidae n. fam.) parasitic in the palm-pollinating weevil Elaeidobius kamerunicus Faust, with a phylogenetic synopsis of the Sphaerularioidea Lubbock, 1861. Systemic Parasitology, 52, 219-225.

Prasetyo, A.E. (2013). Aktivitas Elaeidobius kamerunicus Faust pada berbagai bahan tanaman kelapa sawit yang berpotensi produksi tinggi. Warta Pusat Penelitian Kelapa Sawit, 18(2), 59-65.

Prasetyo, A.E., Arif, M., \& Hidayat, T.C. (2012). Buah landak pada tanaman muda kelapa sawit. Warta Pusat Penelitian Kelapa Sawit, 17(1), 13-20.

Prasetyo, A.E., Purba, W.O., \& Susanto, A. (2014). Elaeidobius kamerunicus: Application of hatch and carry technique for increasing oil palm fruit set. Journal of Oil Palm Research, 26(3), 195-202.

Prasetyo, A.E., Supriyanto, E., Susanto, A., \& Purba, A.R. (2010). Population dynamics of Elaeidobius kamerunicus Faust, a case study on upland oil palm plantation. Proceeding International of Oil Palm Conference. 
Morphometric Analysis of the Oil Palm Pollinating Weevil, Elaeidobius kamerunicus

Rao, V. \& Law, I.H. (1998). The problem of poor fruitset in parts of East Malaysia. The Planter, 74(870), 463-483.

Sambathkumar, S. \& Ranjith, A.M. (2011). Insect pollinators of oil palm in kerala with special reference to african weevil, Elaeidobius kamerunicus Faust. Pest Management in Horticultural Ecosystem, 17(1), 14-18.

Schauble, C.S. (2004). Variation in body size and sexual dimorphism across geographical and environmental space in the frogs Limnodynastes tasmaniensis and L. peronei. Biological Journal of the Linnean Society, 82, 39-56.

Schluter, D. (2000). The ecology of adaptive radiation. Oxford University Press, Oxford, UK, 296 pp.

Setyamidjaja, D. (2006). Kelapa sawit teknik budidaya, panen, dan pengolahan. Kanisius, Yogyakarta.

Siti-Nurlydia, S., Izfa Riza, H., Fatimah, A., Faszly, R., \& Abdul Aziz, J. (2018). Morphometric study of the palm weevils, Rhynchophorus vulneratus and $R$. ferrugineus (Coleoptera: Curculionidae) in view of insular and mainland populations of Malaysia. Pertanika Journal of Tropical Agricultural Science, 41(3), 1329-1340.

Sorbolini, S., Gaspa, G., Steri, R., Dimauro, C., Cellesi, M., Stella, A., Marras, G., Marsan, P.A., Valentini, A., \& Macciotta, N.P.P. (2016). Use of canonical discriminant analysis to study signatures of selection in cattle. Genetic Selection Evolution, 48, 1-13.

Sukhodolskaya, R. (2013). Intraspecific body size variation in ground beetles (Coleoptera, Carabidae) in urban-suburban-rural-natural gradient. Acta Biologica Universitatis Daugavpiliensis, 13(1), 121-128.

Sukhodolskaya, R. (2016). Body size variation of ground beetles (Coleoptera: Carabidae) in latitudinal gradient. Periodicum Biologorum, 118(3), 273-280.

Syed, R.A., Law, I.H., \& Corley, R.H.V. (1982). Insect pollination of oil palm: introduction, establishment and pollinating efficiency of Elaeidobidus kamerunicus in Malaysia. The Planter, 58, 547-561.

Syed, R.A. (1982). Insect pollination of oil palm: feasibility of introducing Elaeidobius spp. into Malaysia [From Africa]. Proc. of the international conference on oil palm in agriculture in the eighties, Pushparajah, E.Chew, PS (eds.)- Kuala Lumpur (Malaysia): PPP ISP, p 263-289.

Teder, T. \& Tammaru, T. (2005). Sexual size dimorphism within species increases with body size in insects. Oikos, 108, 321-334.

Teo, T.M. (2015) Effectiveness of the oil palm pollinating weevil, Elaeidobius kamerunicus, In Malaysia. Utar Agricultural Science Journal, 1(4), 40-43.

Thiago, M.A., Femanda, F.S., \& Marconi, S.S. (2011). Analysis of morphometry and dimorphism in Enhydrus sulcatus (Wiedeman, 1821) (Coleoptera: Gyrinidae). Neotropical Biology and Conservation, 6(3), 178-186.

Tuo, Y., Koua, H.K., \& Hala, N. (2011). Biology of Elaeidobius kamerunicus and Elaeidobius plagiatus (Coleoptera: Curculionidae), main pollinators of oil palm in West Africa. European Journal of Scientific Research, 49(3), 426-432.

Wool, D. \& Hales, D.H. (1997). Phenotypic plasticity in Australian cotton aphid (Homoptera: Aphididae): Host plant effects on morphological variation. Annals of the Entomological Socity of America, 90(3), 316-328.

Zahiri, R., Sarafrazi, A., Salehi, L., \& Kunkel, J.G. (2006). A geometric morphometric study on populations of the rice stem borer, Chilo suppressalis Walker (Lepidoptera: Crambidae) in Northern Iran. Zoology in the Middle East, 38(1), 73-84. 